\title{
Distribution of Heavy Metals in Apple Tissues Grown in the Soils of Industrial Area
}

\author{
Resmije Imeri' ${ }^{1}$ Endrit Kullaj', Lulzim Millaku²* \\ 1 Agricultural University of Tirana, Koder-Kamëz, Tirana, Republic of Albania \\ 2 University of Prishtina, Department of Biology, Republic of Kosovo \\ * Corresponding author's e-mail: lulzimmillaku@hotmail.com
}

\begin{abstract}
The exposure of heavy metals in the Drenas site - Kosovo has risen dramatically in the last 30 years because of mining and smelting activities. The study investigated the heavy metal in soil, accumulation in different parts of apple trees near the industrial sites of Drenas. The accumulation ratio values of heavy metals were calculated to assess the potential health risks. The mean concentrations of the heavy metals in the soil were in the following order of magnitude $\mathrm{Ni}>\mathrm{Zn}>\mathrm{Fe}>\mathrm{Cr}>\mathrm{Cu}>\mathrm{Pb}>\mathrm{Cd}>\mathrm{As}$, while that in the apples were in the order of magnitude $\mathrm{Ni}>\mathrm{Cr}>\mathrm{Fe}>\mathrm{Cu}>\mathrm{Pb}>\mathrm{Zn}>\mathrm{Cd}>\mathrm{As}$, in the leaves $-\mathrm{Fe}>\mathrm{Zn}>\mathrm{Cu}>\mathrm{Cr}>\mathrm{Ni}>\mathrm{Pb}>\mathrm{Cd}>\mathrm{As}$ and in the shoots $-\mathrm{Zn}>\mathrm{Fe}>\mathrm{Cu}>\mathrm{Cr}>\mathrm{Ni}>\mathrm{Pb}>\mathrm{Cd}>$ As. Compared to control, the contents of analyzed metals from plant tissues of apple trees in the contaminated area were significantly higher $(\mathrm{p}<0.001)$. The concentration of $\mathrm{Ni}, \mathrm{Pb}$, $\mathrm{Cr}$, Fe etc. in the apple tissue increased along with the heavy metal content in soils in the polluted area. The high accumulation ratio values for $\mathrm{Pb}(1.1), \mathrm{Cd}(0.62), \mathrm{Cr}(0.93)$ and $\mathrm{Ni}(0.46)$ were characteristic for the investigated species and indicate the accumulation ability.
\end{abstract}

Keywords: toxic/heavy metals, polluted soils, plant/soils, accumulation, distribution, health.

\section{INTRODUCTION}

Today, many studies have focused on soil pollution and the mobilization of heavy metals in living organisms. These studies have often revealed that the environmental pollution by toxic metals has increased steadily since the Industrial Revolution, thereby causing serious ecological problems (Akguc et al. 2008; Huseyinova et al. 2009). Pollution occurs when an element or a substance is present in the concentrations greater than natural (background), as a result of human activity and has a net detrimental effect on the environment and its components. Thus, from a plant, animal, and human health perspective, soils are not considered polluted unless a threshold concentration exists that begins to affect biological processes (Kabata-Pendias et al. 1989).

Food safety is a major public concern around the world. Over the past few years, increased food safety has stimulated the research on the risk associated with the consumption of food products contaminated by pesticides, heavy elements or toxins (D'Mello 2003; De Santis et al. 2007). Heavy metal contamination can occur due to contaminated water, fertilizers and pesticides, industrial emissions. Plants can accumulate trace elements; especially trace metals, in or on their tissues due to their great ability to adapt to variable chemical properties of the environment. Thus, plants are intermediate reservoirs through which trace elements from soils, and partly from waters and air, move to man and animals. The absorption and accumulation of heavy metals in vegetables and fruits are influenced by many factors, including: the concentration of heavy metals in soil, composition and intensity of atmospheric deposition, including precipitations, phase of plant vegetation (Vontsa et al. 1986). Each case of plant pollution is unique and should be studied for a specific environment. There is an increasing awareness that the results of the studies based on 
simulation-type systems cannot be related to those in a natural system. The trace pollutants entering plant tissues are active in metabolic processes, but can also be stored as inactive compounds in cells and on the membranes.

Metals can be transferred from soil pore water into the plants through the roots in the form of dissolved ions (e.g., $\mathrm{Cd}^{2+}$ ) (McLaughlin et al. 2011). Series of complex processes occur in the soil pore water and crop rhizosphere. The degree of metal enrichment in crops can be described with the enrichment factor, which is defined as the ratio of particular element content in a plant to that in soil. Recently, the application of enrichment factor in the form of transfer factor, bio concentration factor (BCF), and plant uptake factor has been expanded to the research on soil, water system, and sediment, as well as assessment of heavy metal pollution in environmental geochemistry (Khan et al. 2010; Brioschi et al. 2013). BCF is an important quantitative indicator of crop contamination and has commonly been used for estimating the metal transfer from soil into plants (García et al. 2009). In order to ensure soil quality and prevent the accumulation of toxic heavy metals in plants, it is essential to understand the dynamics of heavy metals in the soil-leaf-fruit system, since their presence in soils does not necessarily imply their adverse effects if they do not occur in a form that is easily absorbed by plants. Moreover, while assessing the usability of a soil for agricultural production with respect to heavy metal contamination, it is vitally important that careful consideration be given to the chemical properties of the soil and their effect on the uptake, transport and accumulation of heavy metals in the plant.

To this end, the present study assessed the extent of heavy metal accumulation in apple tissues commonly grown in agricultural areas in the Drenas region. It is essential to investigate the heavy metal dynamics in the soil-leaf-fruit system in fruit crops as these provide staple food for human diet. Given the above, the objective of the present study was to evaluate the dynamics of heavy metals $\mathrm{Pb}, \mathrm{Cd}, \mathrm{Cr}, \mathrm{Ni}, \mathrm{As}, \mathrm{Zn}, \mathrm{Cu}$ and $\mathrm{Fe}$ in an intensive apple (Deleciose, cv. Supercheef) planting located in the region of Drenas, and give insight into the potential for safe fruit production on the study location. However, this study aimed 1) at investigating the level of heavy metal contamination in the soil, 2) studying bioaccumulation of heavy metals in growing plants in the Drenas region and 3) identifying which rootstock used is the largest barrier in the accumulation of heavy metals in fruit trees.

\section{MATERIALS AND METHODS}

\section{Description of the Study area:}

The present study was conducted in the Drenas town, an urban area located 20 kilometers far from Prishtina (capital of Republic of Kosovo) in the west, one of the important mining and smelting locations in Kosovo (Fig. 1). The smelter (Ferronickel) has operated since 1982. The Ferronikel complex has three open pit mines: the Dushkaja mine with estimated reserves of 6.2 million tonnes; the Suka mine -0.8 million tonnes and the Gllavica with 6.8 million tonnes. The Ferronikeli smelter is well-known for the final production of Ferro- nickel. In metallurgical processing, the mineral base is treated by an oxide mineral of nickel (two sources) with the following average chemical structure: $\mathrm{Ni}+\mathrm{Co}=1.2 \% ; \mathrm{Fe}=26.0 \%$; $\mathrm{SiO}_{2}=47.0 \% ; \quad \mathrm{CaO}=2.5 \% ; \quad \mathrm{Cr}_{2} \mathrm{O}_{3}=1.2 \%$; $\mathrm{MgO}=11.0 \%$. The produced slag has the following chemical structure: $\mathrm{Ni}-0-08 \% ; \mathrm{SiO}_{2} 55-57 \%$; $\mathrm{MgO} 10.0 \%$; Fe total $20 \%$; Ca) $4.0 \%$. The capacity of the smelter in the technological lines (rotating furnace and electrical furnace) is about $12.000 \mathrm{t} \mathrm{Ni} /$ year (Rizaj et al. 2008). In recent times, the smelter plant is has been active and it is known as "New CO Ferronickel".

\section{Sample collection}

The sampling locations were chosen near farmland and industrial areas. Individual soil samples were collected from each plant to assess the metal content in the immediate plant environment. The samples of fruits, leaf, shoots and soil were analysed for eight heavy metals $(\mathrm{Pb}, \mathrm{Cd}, \mathrm{As}$, $\mathrm{Ni}, \mathrm{Zn}, \mathrm{Cu}, \mathrm{Cr}$ and $\mathrm{Fe}$ ). In total, 20 samples of soil and 90 apple samples were collected in the Drenas region and the reference area during SeptemberNovember 2017 (Fig. 1). Three kinds of apple tissues were collected during the harvest period, including fruits, leaf and shoots. In order to reduce the effect of other agro environmental factors on the issue analysed, the experiment included a row of fruit trees with the same age (6 years), grafted on the same rootstock $(\mathrm{mm} 106, \mathrm{~m} 26, \mathrm{~m} 9)$. The soil samples were taken from the surface layer $(0-20 \mathrm{~cm})$. All the samples were sealed in polyethylene bags and transported to the laboratory within $6 \mathrm{~h}$ of collection. The soil samples were air-dried at room temperature, with impurities manually removed. Then, the soils were ground 


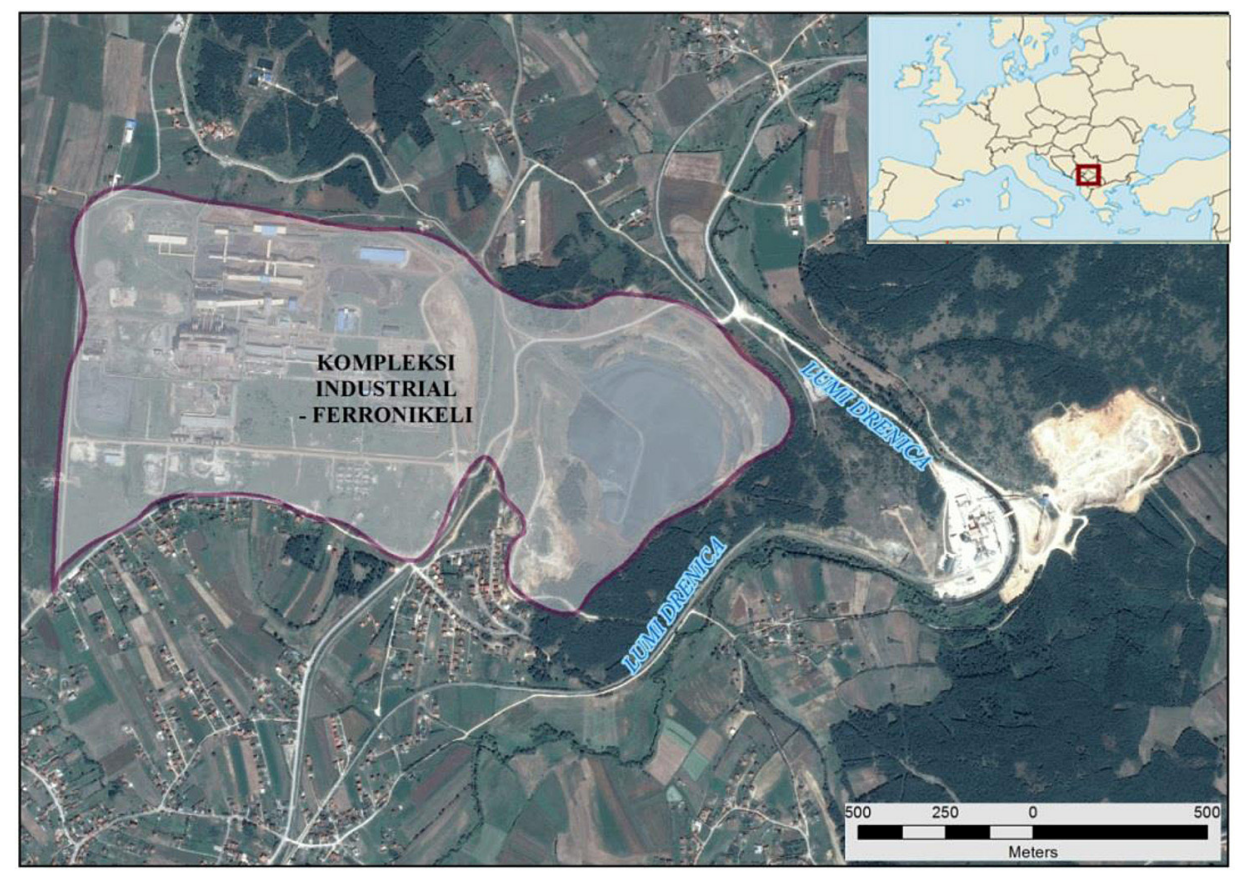

Figure 1. View from the studied area - Drenas

and sieved through 80 meshes $(0.2 \mathrm{~mm})$. For all samples, the decay and withered tissues were removed and the edible parts were washed with tap water to remove the surface dirt. The edible parts of fruits or leaf were repeatedly rinsed with deionised water and dried at $60^{\circ} \mathrm{C}$ to a constant weight.

\section{Sample analysis}

For the research needs of the metal content: Lead $(\mathrm{Pb})$, Cadmium (Cd), Chromium (Cr), Nickel (Ni), Arsenic (As), Zinc (Zn), Copper $(\mathrm{Cu})$, Iron $(\mathrm{Fe})$, the field samples were obtained in accordance with the respective protocols and consisted in sampling the soil from apple planted surfaces within the respective localities. The samples obtained were labelled with all relevant data (location, sampling date, and other notes). The concentration of metals in the soil samples was determined by the Atomic Spectrometer Absorber (AAS) of the Perkin-Elmer model 1200 mark. The work samples (2.0 gr of soil sample) were treated with a $1: 3$ aqueous regia mixture $\left(4 \mathrm{ml} \mathrm{HNO}_{3}+\right.$ $12 \mathrm{ml}$ of concentrated $\mathrm{HCl}$ ) in an electrical reso at a temperature of $200^{\circ} \mathrm{C}$ for 60 minutes. Prior to mineralization with aqua regia, the organic matter was disintegrated with concentrated hydrogen peroxide $\left(35 \% \mathrm{H}_{2} \mathrm{O}_{2}\right)$. Then, the mineralized samples were mixed with distilled water and filtered with Watman $0.45 \mu \mathrm{m}$ filtration paper. The filter was placed on a volumetric balloon of $50 \mathrm{~cm}^{3}$ and levelled up to the mark with distilled water. Such samples were read with AAS and spectrophotometer. The AAS calibration was done with the standard reference material of $1000 \mathrm{ppm}(\mathrm{mg} /$ $\mathrm{kg}$ ) from which the respective metal standards were prepared. BCF was calculated for different plant parts (shoot, leaf and fruits) by the following equation: $\mathrm{BCF}=$ metal in plant part/metal in soil $\left(\mathrm{mg} \mathrm{kg}^{-1} \mathrm{dw}\right)$.

\section{Statistical analysis}

The data were statistically analyzed using GraphPad Prism - version 7.05, and Microsoft Excel, 2010, computer packages. Pearson correlation coefficients were calculated to determine the relationship between heavy metal contents in the fruits, leaf, shoot and in the soils. The level of significance was set at $\mathrm{p}<0.05$.

\section{RESULTS AND DISCUSSION}

The concentrations of heavy metals $\mathrm{Pb}, \mathrm{Cd}$, $\mathrm{Cr}, \mathrm{Ni}, \mathrm{As}, \mathrm{Zn}, \mathrm{Cu}$ and $\mathrm{Fe}$ in the apple tissues (delicious, cv. supercheef) varies depending on the type of rootstock. Table 1 shows the distribution values of the heavy metals in soils and the analyzed tissues (fruit, leaves and shoots) of the apple sp. with rootstock $\mathrm{mm} 106, \mathrm{~m} 26, \mathrm{~m} 9$ in the region of Drenas. 
Comparisons were made by analyzing the same element and subtype types with the reference area - Kovrage, Table 2. The analyses in soil samples show these values: $\mathrm{Pb}-2.44 \mathrm{mg} / \mathrm{kg}$, $\mathrm{Cd}-0.39 \mathrm{mg} / \mathrm{kg}, \mathrm{Cr}-13.4 \mathrm{mg} / \mathrm{kg}, \mathrm{Ni}-33.12 \mathrm{mg} / \mathrm{kg}$, As- $-0.007 \mathrm{mg} / \mathrm{kg}, \mathrm{Zn}-20.69 \mathrm{mg} / \mathrm{kg}, \mathrm{Cu}-11.3 \mathrm{mg} / \mathrm{kg}$ and $\mathrm{Fe}-15.96 \mathrm{mg} / \mathrm{kg}$. The distribution of heavy elements in soil was followed by this sequence: $\mathrm{Ni}>\mathrm{Zn}>\mathrm{Fe}>\mathrm{Cr}>\mathrm{Cu}>\mathrm{Pb}>\mathrm{Cd}>$ As. The $\mathrm{pH}$ values in all analyzed soil samples were distributed from 6.45 to 7.8 , indicating that the soil analyzed was neutral and basically weak. The general concentrations of metals in soils between the two analyzed regions (Drenas and the reference site) showed significant differences in scale.

As compared to the soils, the apple tree tissues contained less heavy metals with obvious variations among different rootstocks (table 1). The concentrations of $\mathrm{Pb}$ in tissues with different rootstocks were $0.17-1.55 \mathrm{mg} \mathrm{kg}^{-1}$ (mm106), 0.07-1.49 (m26) and 0.08-2.17 (m9). The Cd values in fruit were $0.05-0.21$ (mm106), 0.090.17 (m26), 0.02-0.18 (m9). The Cr values were: 3.12-11.6 (mm106), 3.38-8.22 (m26), 2.81-8.31 (m9). The Ni values were: 0.79-17.2 (mm106), 0.24-16.5 (m26), 0.49-15.33 (m9). Arsenic was not detected in plant tissue with rootstock $\mathrm{mm}$ 106 and $\mathrm{m} 26$, while in the fruits with rootstock $\mathrm{m} 9$, the recorded value was: $0.009 \mathrm{mg} \mathrm{kg}^{-1}$. The $\mathrm{Zn}$ values were: $1.51-65.2$ (mm106), 1.78-81.1 (m26), 2.03-59.2 (m9). The $\mathrm{Cu}$ values were: 2.24-19.3 (mm106), 2.87-23.1 (m26), 2.05-24.2 (m9). The Fe values reached: 2.49-76.4 (mm106), 2.27-23.1 (m26), 2.05-24.2 (m9). These results

Table 1. Heavy metal concentration $\left(\mathrm{mg} \mathrm{kg}^{-1}\right)$ in soil, shoot, leaf and fruits of apple species depending on rootstocks type from Drenas region

\begin{tabular}{|c|c|c|c|c|c|c|c|c|c|c|}
\hline \multicolumn{3}{|c|}{ Specification } & \multicolumn{8}{|c|}{ Heavy metals $\left(\mathrm{mg} / \mathrm{kg}^{-1}\right)$} \\
\hline Rootstock & Tissues & Level & $\mathrm{Pb}$ & $\mathrm{Cd}$ & $\mathrm{Cr}$ & $\mathrm{Ni}$ & As & $\mathrm{Zn}$ & $\mathrm{Cu}$ & $\mathrm{Fe}$ \\
\hline \multirow{9}{*}{ M106 } & \multirow{3}{*}{ shoot } & Mean & 1.21 & 0.21 & 3.12 & 1.58 & nd & 65.2 & 19.3 & 58.5 \\
\hline & & $\mathrm{SD}( \pm)$ & 0.52 & 0.17 & 1.15 & 0.67 & & 8.86 & 6.17 & 15.2 \\
\hline & & CV $(\%)$ & 42.9 & 80.9 & 36.8 & 42.4 & & 13.5 & 31.9 & 25.9 \\
\hline & \multirow{3}{*}{ leaf } & Mean & 0.17 & 0.05 & 5.53 & 0.79 & nd & 25.5 & 9.62 & 76.4 \\
\hline & & $\mathrm{SD}( \pm)$ & 0.08 & 0.04 & 2.19 & 0.31 & & 4.7 & 3.57 & 10.1 \\
\hline & & $\mathrm{CV}(\%)$ & 47.1 & 80 & 39.6 & 39.2 & & 18.4 & 37.1 & 13.2 \\
\hline & \multirow{3}{*}{ fruits } & Mean & 1.55 & 0.21 & 11.6 & 17.2 & nd & 1.51 & 2.24 & 2.49 \\
\hline & & $\mathrm{SD}( \pm)$ & 1.09 & 0.02 & 4.74 & 8.06 & & 0.99 & 1.74 & 1.33 \\
\hline & & CV $(\%)$ & 70.3 & 9.52 & 40.8 & 46.8 & & 65.5 & 77.6 & 53.4 \\
\hline \multirow{9}{*}{ M26 } & \multirow{3}{*}{ shoot } & Mean & 0.89 & 0.17 & 3.38 & 1.18 & nd & 81.1 & 23.1 & 73.5 \\
\hline & & $\operatorname{SD}( \pm)$ & 0.47 & 0.11 & 1.13 & 0.41 & & 8.53 & 5.96 & 9.97 \\
\hline & & CV (\%) & 52.8 & 64.7 & 33.4 & 34.7 & & 10.5 & 25.8 & 13.5 \\
\hline & \multirow{3}{*}{ leaf } & Mean & 0.07 & 0.09 & 4.34 & 0.24 & nd & 37.5 & 12.4 & 91.1 \\
\hline & & $\mathrm{SD}( \pm)$ & 0.05 & 0.05 & 1.18 & 0.54 & & 6.85 & 4.03 & 10.8 \\
\hline & & CV (\%) & 71.4 & 55.5 & 27.1 & 225 & & 18.2 & 32.5 & 11.8 \\
\hline & \multirow{3}{*}{ fruits } & Mean & 1.49 & 0.17 & 8.22 & 16.5 & nd & 1.78 & 2.87 & 2.27 \\
\hline & & $\mathrm{SD}( \pm)$ & 0.63 & 0.11 & 2.84 & 3.47 & & 0.68 & 0.88 & 0.94 \\
\hline & & CV (\%) & 42.2 & 64.7 & 34.5 & 21.1 & & 38.2 & 30.6 & 41.4 \\
\hline \multirow{9}{*}{ M9 } & \multirow{3}{*}{ shoot } & Mean & 0.94 & 0.12 & 3.63 & 1.34 & nd & 59.2 & 24.2 & 62.3 \\
\hline & & $\mathrm{SD}( \pm)$ & 0.38 & 0.07 & 0.41 & 0.5 & & 7.16 & 5.85 & 10.4 \\
\hline & & CV (\%) & 40.4 & 58.3 & 11.2 & 37.3 & & 12.1 & 24.1 & 16.7 \\
\hline & \multirow{3}{*}{ leaf } & Mean & 0.08 & 0.02 & 2.81 & 0.49 & nd & 22.2 & 15.9 & 106.1 \\
\hline & & $\mathrm{SD}( \pm)$ & 0.05 & 0.02 & 0.99 & 0.42 & & 5.51 & 5.43 & 11.22 \\
\hline & & CV (\%) & 62.5 & 100 & 35.2 & 85.7 & & 24.8 & 34.1 & 10.5 \\
\hline & \multirow{3}{*}{ fruits } & Mean & 2.17 & 0.18 & 8.31 & 15.33 & 0.009 & 2.03 & 2.05 & 3.12 \\
\hline & & $\operatorname{SD}( \pm)$ & 1.69 & 0.09 & 4.47 & 6.77 & 0.001 & 0.91 & 1.39 & 1.64 \\
\hline & & CV (\%) & 77.8 & 50 & 53.7 & 44.1 & 11.1 & 44.8 & 67.8 & 52.5 \\
\hline \multirow{3}{*}{ Soils } & & Mean & 2.44 & 0.39 & 13.4 & 33.12 & 0.007 & 20.69 & 11.3 & 15.96 \\
\hline & & $\mathrm{SD}( \pm)$ & 1.63 & 0.11 & 2.34 & 19.7 & 0.001 & 6.77 & 2.24 & 3.32 \\
\hline & & CV (\%) & 66.8 & 28.2 & 17.4 & 59.4 & 14.2 & 32.7 & 19.8 & 20.8 \\
\hline
\end{tabular}

Note: Values are expressed as means $\mathrm{X}$ and $\pm \mathrm{SD} . \mathrm{Nd}$ - not detected. 
demonstrate that $\mathrm{Pb}, \mathrm{Cd}, \mathrm{Cr}, \mathrm{Ni}$ and $\mathrm{As}$ are the dominant metal pollutants accumulated in fruits apple grown in the agricultural soils in the Drenas region. On the other hand, $\mathrm{Zn}, \mathrm{Cu}$ and $\mathrm{Fe}$ are the dominant metals accumulated in the shoots and leaf to apple tree in this region. In $\mathrm{m} 26$ and $\mathrm{m} 9$ rootstocks, the largest quantity of $\mathrm{Pb}$ is stored in the fruit. The highest amount of $\mathrm{Cd}$ is stored on the fruit and is registered in the mm106 rootstock. Chromium and $\mathrm{Ni}$ were mostly stored in the fruit at the three studied rootstock. Arsenic was detected in the highest amount only in the $\mathrm{m} 9$ rootstock while in other rootstock, it was not detected at all. Zinc and copper in the highest amount were found in shoots in three different rootstocks. The analyses conducted for heavy metals in plant tissues showed high levels of accumulation of $\mathrm{Zn}$ in leaves and shoot compared with the amount of $\mathrm{Cu}$. This is known as an antagonist effect.
The following results represent a rootstock that tends to accumulate more severe elements: $\mathrm{Pb}$ /fruit: $\mathrm{m} 9>\mathrm{mm} 106>\mathrm{m} 26$; $\mathrm{Cd} /$ fruit: mm106> $\mathrm{m} 9>\mathrm{m} 26$; Cr/ fruit: $\mathrm{mm} 106>\mathrm{m} 9>\mathrm{m} 26$;

$\mathrm{Ni} /$ fruit: mm106 > m26> m9; As/fruit: m9> mm106 > m26; Zn/shoot: $\mathrm{m} 26>\mathrm{m} 9>\mathrm{mm} 106$; $\mathrm{Cu} /$ shoot: $\mathrm{m} 9>\mathrm{m} 26>\mathrm{mm} 106$; Fe/leaf: $\mathrm{m} 9>$ $\mathrm{m} 26>\mathrm{mm} 106$. On the basis of the obtained results it was observed that the cultivar with rootstock mm106 has a high tendency to absorb heavy metals (lead, cadmium, chromium, nickel, arsenic) with toxicity. Meanwhile, $\mathrm{m} 9$ rootstock has a tendency to absorb the elements that are necessary for the plant $(\mathrm{Fe}, \mathrm{Cu})$.

$\mathrm{BCF}$ is an index for assessing the possible transfer of a metal from soil to plants versus fruit ability to accumulate a particular metal with respect to its concentration on the substrate of the earth (Adamo et al., 2014). Bioaccumulation

Table 2. Heavy metal concentration $\left(\mathrm{mg} \mathrm{kg}^{-1}\right)$ in soil, shoot, leaf and fruits of apple species depending on rootstocks type from Reference site

\begin{tabular}{|c|c|c|c|c|c|c|c|c|c|c|}
\hline \multicolumn{3}{|c|}{ Specification } & \multicolumn{8}{|c|}{ Heavy metals $\left(\mathrm{mg} / \mathrm{kg}^{-1}\right)$} \\
\hline Rootstock & Tissues & Level & $\mathrm{Pb}$ & $\mathrm{Cd}$ & $\mathrm{Cr}$ & $\mathrm{Ni}$ & As & $\mathrm{Zn}$ & $\mathrm{Cu}$ & $\mathrm{Fe}$ \\
\hline \multirow{9}{*}{ M106 } & \multirow{3}{*}{ shoot } & Mean & 3.23 & 0.23 & 0.26 & 3.76 & nd & 56.17 & 5.12 & 34.05 \\
\hline & & $\mathrm{SD}( \pm)$ & 1.09 & 0.17 & 0.18 & 0.54 & & 10.3 & 0.91 & 4.16 \\
\hline & & CV (\%) & 33.7 & 73.9 & 69.2 & 14.3 & & 18.3 & 17.7 & 12.2 \\
\hline & \multirow{3}{*}{ leaf } & Mean & 1.69 & 0.16 & 1.13 & 0.93 & nd & 23.2 & 8.55 & 79.14 \\
\hline & & $\mathrm{SD}( \pm)$ & 0.81 & 0.15 & 0.19 & 0.47 & & 4.67 & 2.63 & 4.51 \\
\hline & & CV (\%) & 47.9 & 93.7 & 16.8 & 50.5 & & 20.1 & 30.7 & 5.69 \\
\hline & \multirow{3}{*}{ fruits } & Mean & 0.51 & 0.009 & 1.27 & 0.28 & nd & 0.88 & 0.98 & 3.36 \\
\hline & & $\mathrm{SD}( \pm)$ & 0.34 & 0.001 & 0.63 & 0.07 & & 0.44 & 0.32 & 1.79 \\
\hline & & CV (\%) & 66.6 & 11.1 & 49.6 & 25 & & 50 & 32.6 & 53.2 \\
\hline \multirow{9}{*}{ M26 } & \multirow{3}{*}{ shoot } & Mean & 2.65 & 0.17 & 0.18 & 2.44 & nd & 48.02 & 6.31 & 41.03 \\
\hline & & $\operatorname{SD}( \pm)$ & 1.69 & 0.24 & 0.11 & 1.08 & & 11.03 & 1.41 & 4.37 \\
\hline & & CV (\%) & 63.7 & 141.1 & 61.1 & 44.2 & & 22.9 & 22.3 & 10.6 \\
\hline & \multirow{3}{*}{ leaf } & Mean & 1.38 & 0.19 & 1.06 & 0.41 & nd & 41.15 & 11.7 & 104.3 \\
\hline & & $\mathrm{SD}( \pm)$ & 0.7 & 0.16 & 0.43 & 0.33 & & 6.66 & 3.92 & 9.55 \\
\hline & & CV (\%) & 50.7 & 84.2 & 40.5 & 80.4 & & 16.1 & 33.5 & 9.15 \\
\hline & \multirow{3}{*}{ fruits } & Mean & 0.38 & 0.08 & 0.99 & 0.18 & nd & 0.74 & 0.78 & 3.23 \\
\hline & & $\mathrm{SD}( \pm)$ & 0.26 & 0.05 & 0.58 & 0.17 & & 0.36 & 0.56 & 0.74 \\
\hline & & CV (\%) & 68.4 & 62.5 & 58.5 & 94.4 & & 48.6 & 71.7 & 22.9 \\
\hline \multirow{9}{*}{ M9 } & \multirow{3}{*}{ shoot } & Mean & 2.12 & 0.13 & 0.42 & 3.33 & nd & 62.11 & 4.97 & 36.14 \\
\hline & & $\mathrm{SD}( \pm)$ & 1.05 & 0.09 & 0.14 & 1.38 & & 12.17 & 1.65 & 6.09 \\
\hline & & CV (\%) & 49.5 & 69.2 & 33.3 & 41.4 & & 19.5 & 33.1 & 16.8 \\
\hline & \multirow{3}{*}{ leaf } & Mean & 0.85 & 0.06 & 0.86 & 0.31 & nd & 29.2 & 9.84 & 94.9 \\
\hline & & $\operatorname{SD}( \pm)$ & 0.82 & 0.04 & 0.28 & 0.28 & & 6.96 & 2.93 & 11.24 \\
\hline & & CV (\%) & 96.4 & 66.6 & 32.5 & 90.3 & & 23.8 & 29.7 & 11.8 \\
\hline & \multirow{3}{*}{ fruits } & Mean & 0.31 & 0.003 & 0.49 & 0.19 & nd & 0.31 & 0.93 & 4.13 \\
\hline & & $\mathrm{SD}( \pm)$ & 0.21 & 0.001 & 1.37 & 0.27 & & 0.13 & 0.87 & 2.59 \\
\hline & & CV (\%) & 67.7 & 33.3 & 279.5 & 142.1 & & 41.9 & 93.5 & 62.7 \\
\hline \multirow{3}{*}{ Soils } & & Mean & 1.03 & 0.05 & 0.39 & 1.99 & nd & 4.72 & 1.92 & 9.22 \\
\hline & & SD $( \pm)$ & 0.66 & 0.009 & 0.31 & 1.43 & & 1.14 & 0.39 & 3.58 \\
\hline & & CV (\%) & 64.1 & 18 & 79.4 & 71.8 & & 24.1 & 20.3 & 38.8 \\
\hline
\end{tabular}

Note: Values are expressed as means $\mathrm{X}$ and $\pm \mathrm{SD}$. nd - not detected 
Factor (BCF) table 3 summarizes the BF value in the study area. The plant species apple delishese in fruits showed higher $\mathrm{BF}$ values for $\mathrm{Pb}: \mathrm{m} 9>$ mm106 > m26 (1.1, 0.61, 0.57); Cd: mm106> $\mathrm{m} 9>\mathrm{m} 26(0.62,0.51,0.44) \mathrm{Cr}: \mathrm{mm} 106>\mathrm{m} 9>$ m26 (0.93, 0.66, 0.65). Similarly, leaf and shoot showed high $\mathrm{BF}$ value for $\mathrm{Fe}, \mathrm{Cu}$ and $\mathrm{Zn}$. The concentrations of heavy metals in mine soil are almost high as compared to plants, and the bioaccumulation value is restricted to all most all plant species of the study area.

This restriction of heavy metals can be due to physical parameters like PH, EC of soil and metals resistance in plant body (Gupta et al. 2008). The concentrations of heavy metals in fruits also exhibit significant differences between samples, which shows the high variation coefficient (CV) (ranging from 62.8 to $185.7 \%$ ) in table 1 . The correlation between the heavy metals in the soil and the plant tissues are presented in the tables 4, 5, and 6. On the basis of the presented results and the correlation analysis, most metals did not show correlation. However, some metals indicated correlation, so in shoots with rootstock mm106, Cd showed high correlation with $\mathrm{Cr}$ and $\mathrm{Ni}(\mathrm{r}=0.718$ and $r=0.728)$. The same correlation $\mathrm{Cd}$ was also shown with $\mathrm{Ni}$ and $\mathrm{Cu}$ in fruits with rootstock $\operatorname{mm} 106(r=0.691$ and $r=0.759)$.
In the $\mathrm{m} 26$ rootstock, there was a significant negative correlation $(\mathrm{r}=-0.742)$ between $\mathrm{Pb}$ and $\mathrm{Cr}$. Negative correlation is also present between $\mathrm{Zn}$ and $\mathrm{Cu}$ in the leaves $(\mathrm{r}=-0.808)$. A negative correlation $(\mathrm{r}=-0.791)$ between the $\mathrm{Cd}$ and $\mathrm{Fe}$ in the shoot tissue was observed in $\mathrm{m} 9$ rootstock.

The positive correlation was observed in the leaves between $\mathrm{Pb}$ and $\mathrm{Cd}(\mathrm{r}=0.706)$ while negative between $\mathrm{Cd}$ and $\mathrm{Zn}(\mathrm{r}=-0.764)$. The positive correlation in fruit was found between $\mathrm{Cd}$ and $\mathrm{Cr}$ $(\mathrm{r}=0.632)$ and between $\mathrm{Cd}$ and $\mathrm{Zn}(\mathrm{r}=0.681)$. In this study, the concentrations of heavy metals analyzed in apple tissues and especially in fruit were tens of times higher than the allowed maximum limits. The obtained results showed that the fruits were powerful accumulators of heavy metals, considering that for some types of rootstocks, the concentrations of heavy metals in the samples exceeded the allowed values.

Our results are in line with those reported by Zhen et al. (2008), Xiao et al. (2010) in China. Zhen (2008) reported that cultivated fruits near the Shenyang-Dalian highway were polluted with $\mathrm{Pb}$ and $\mathrm{Cd}$ with average concentrations of 0.082 and $0.010 \mathrm{mg} / \mathrm{kg}$ in apple fruit. The fruits cultivated in the mining areas were prone to contamination with heavy metals (Xiao et al., 2010). The results of the present work exhibited differential

Table 3. BCF of heavy metals in plant species of the study area

\begin{tabular}{|c|c|c|c|c|c|c|c|c|c|}
\hline \multirow{2}{*}{$\begin{array}{l}\mathrm{BCF}=\mathrm{Cp} / \mathrm{Cs} \\
\text { Heavy metals }\end{array}$} & \multicolumn{4}{|c|}{ Drenas region } & \multirow{2}{*}{$\begin{array}{l}\mathrm{BCF}=\mathrm{Cp} / \mathrm{Cs} \\
\text { Heavy metals }\end{array}$} & \multicolumn{4}{|c|}{ Reference site } \\
\hline & Rootstock & Leaf & Shoot & Fruits & & Rootstock & Leaf & Shoot & Fruits \\
\hline $\mathrm{Ni}$ & $\begin{array}{c}\text { MM106 } \\
\text { M26 } \\
\text { M9 }\end{array}$ & $\begin{array}{l}0.02 \\
0.04 \\
0.01\end{array}$ & $\begin{array}{l}1.08 \\
0.03 \\
0.03\end{array}$ & $\begin{array}{l}0.46 \\
0.44 \\
0.41\end{array}$ & $\mathrm{Ni}$ & $\begin{array}{c}\text { MM106 } \\
\text { M26 } \\
\text { M9 }\end{array}$ & $\begin{array}{l}0.42 \\
0.17 \\
0.13\end{array}$ & $\begin{array}{l}1.63 \\
1.05 \\
1.44\end{array}$ & $\begin{array}{l}0.12 \\
0.07 \\
0.08\end{array}$ \\
\hline $\mathrm{Pb}$ & $\begin{array}{c}\text { MM106 } \\
\text { M26 } \\
\text { M9 }\end{array}$ & $\begin{array}{l}0.06 \\
0.04 \\
0.03\end{array}$ & $\begin{array}{l}0.47 \\
0.34 \\
0.19\end{array}$ & $\begin{array}{l}0.61 \\
0.57 \\
1.11\end{array}$ & $\mathrm{~Pb}$ & $\begin{array}{c}\text { MM106 } \\
\text { M26 } \\
\text { M9 }\end{array}$ & $\begin{array}{l}1.81 \\
1.55 \\
1.92\end{array}$ & $\begin{array}{l}3.62 \\
2.97 \\
2.38\end{array}$ & $\begin{array}{l}0.57 \\
0.42 \\
0.34\end{array}$ \\
\hline $\mathrm{Cd}$ & $\begin{array}{l}\text { MM106 } \\
\text { M26 } \\
\text { M9 }\end{array}$ & $\begin{array}{l}0.14 \\
0.21 \\
0.05\end{array}$ & $\begin{array}{l}0.61 \\
0.48 \\
0.34\end{array}$ & $\begin{array}{l}0.62 \\
0.44 \\
0.51\end{array}$ & $\mathrm{Cd}$ & $\begin{array}{c}\text { MM106 } \\
\text { M26 } \\
\text { M9 }\end{array}$ & $\begin{array}{l}2.14 \\
2.71 \\
0.85\end{array}$ & $\begin{array}{l}3.28 \\
2.42 \\
1.85\end{array}$ & $\begin{array}{l}1.28 \\
1.14 \\
0.04\end{array}$ \\
\hline As & $\begin{array}{l}\text { MM106 } \\
\text { M26 } \\
\text { M9 }\end{array}$ & $\begin{array}{l}\mathrm{Nd} \\
\mathrm{Nd} \\
\mathrm{Nd}\end{array}$ & $\begin{array}{l}\mathrm{Nd} \\
\mathrm{Nd} \\
\mathrm{Nd}\end{array}$ & $\begin{array}{l}\mathrm{Nd} \\
\mathrm{Nd} \\
\mathrm{Nd}\end{array}$ & As & $\begin{array}{c}\text { MM106 } \\
\text { M26 } \\
\text { M9 }\end{array}$ & $\begin{array}{l}\mathrm{Nd} \\
\mathrm{Nd} \\
\mathrm{Nd}\end{array}$ & $\begin{array}{l}\mathrm{Nd} \\
\mathrm{Nd} \\
\mathrm{Nd}\end{array}$ & $\begin{array}{l}\mathrm{Nd} \\
\mathrm{Nd} \\
\mathrm{Nd}\end{array}$ \\
\hline $\mathrm{Zn}$ & $\begin{array}{l}\text { MM106 } \\
\text { M26 } \\
\text { M9 }\end{array}$ & $\begin{array}{l}1.08 \\
1.63 \\
0.94\end{array}$ & $\begin{array}{l}2.72 \\
3.46 \\
2.52\end{array}$ & $\begin{array}{l}0.06 \\
0.07 \\
0.08\end{array}$ & $\mathrm{Zn}$ & $\begin{array}{c}\text { MM106 } \\
\text { M26 } \\
\text { M9 }\end{array}$ & $\begin{array}{c}6.74 \\
11.9 \\
8.4\end{array}$ & $\begin{array}{l}16.3 \\
13.9 \\
18.1\end{array}$ & $\begin{array}{l}0.25 \\
0.21 \\
0.08\end{array}$ \\
\hline $\mathrm{Cr}$ & $\begin{array}{l}\text { MM106 } \\
\text { M26 } \\
\text { M9 }\end{array}$ & $\begin{array}{l}0.44 \\
0.34 \\
0.22\end{array}$ & $\begin{array}{l}0.25 \\
0.27 \\
0.29\end{array}$ & $\begin{array}{l}0.93 \\
0.65 \\
0.66\end{array}$ & $\mathrm{Cr}$ & $\begin{array}{c}\text { MM106 } \\
\text { M26 } \\
\text { M9 }\end{array}$ & $\begin{array}{l}1.18 \\
1.11 \\
0.91\end{array}$ & $\begin{array}{l}0.27 \\
0.18 \\
0.14\end{array}$ & $\begin{array}{l}1.33 \\
1.04 \\
0.51\end{array}$ \\
\hline $\mathrm{Fe}$ & $\begin{array}{l}\text { MM106 } \\
\text { M26 } \\
\text { M9 }\end{array}$ & $\begin{array}{l}4.96 \\
5.91 \\
6.88\end{array}$ & $\begin{array}{l}3.79 \\
4.77 \\
4.04\end{array}$ & $\begin{array}{l}0.16 \\
0.14 \\
0.21\end{array}$ & $\mathrm{Fe}$ & $\begin{array}{l}\text { MM106 } \\
\text { M26 } \\
\text { M9 }\end{array}$ & $\begin{array}{l}10.2 \\
13.5 \\
12.3\end{array}$ & $\begin{array}{l}4.42 \\
5.32 \\
4.68\end{array}$ & $\begin{array}{l}0.43 \\
0.41 \\
0.53\end{array}$ \\
\hline $\mathrm{Cu}$ & $\begin{array}{l}\text { MM106 } \\
\text { M26 } \\
\text { M9 }\end{array}$ & $\begin{array}{l}0.59 \\
0.77 \\
0.98\end{array}$ & $\begin{array}{l}1.19 \\
1.43 \\
1.51\end{array}$ & $\begin{array}{l}0.13 \\
0.17 \\
0.21\end{array}$ & $\mathrm{Cu}$ & $\begin{array}{c}\text { MM106 } \\
\text { M26 } \\
\text { M9 }\end{array}$ & $\begin{array}{l}2.78 \\
3.81 \\
3.21\end{array}$ & $\begin{array}{l}1.65 \\
2.05 \\
1.61\end{array}$ & $\begin{array}{l}0.31 \\
0.25 \\
0.31\end{array}$ \\
\hline
\end{tabular}

Note: $\mathrm{BCF}$ - bioaccumulation factor. 
Table 4. Calculation of correlation coefficient (r) between heavy metals in soil, shoot, leaf and fruit to apple cultivar (delicious $\mathrm{v}$. supercheef) with mm106 rootstock

\begin{tabular}{|c|c|c|c|c|c|c|c|c|}
\hline & $\mathrm{Pb}$ & $\mathrm{Cd}$ & $\mathrm{Cr}$ & $\mathrm{Ni}$ & As & $\mathrm{Zn}$ & $\mathrm{Cu}$ & $\mathrm{Fe}$ \\
\hline \multicolumn{9}{|l|}{ Soil } \\
\hline $\mathrm{Pb}$ & 1.000 & 0.042 & -0.114 & 0.182 & -0.423 & -0.221 & 0.578 & 0.357 \\
\hline $\mathrm{Cd}$ & & 1.000 & -0.216 & 0.131 & -0.364 & -0.378 & 0.531 & -0.064 \\
\hline $\mathrm{Cr}$ & & & 1.000 & -0.354 & 0.309 & 0.484 & -0.503 & 0.037 \\
\hline $\mathrm{Ni}$ & & & & 1.000 & -0.485 & 0.182 & 0.511 & 0.186 \\
\hline As & & & & & 1.000 & -0.147 & -0.456 & -0.162 \\
\hline $\mathrm{Zn}$ & & & & & & 1.000 & -0.339 & 0.248 \\
\hline $\mathrm{Cu}$ & & & & & & & 1.000 & -0.079 \\
\hline $\mathrm{Fe}$ & & & & & & & & 1.000 \\
\hline \multicolumn{9}{|l|}{ Shoot } \\
\hline $\mathrm{Pb}$ & 1.000 & -0.384 & -0.237 & -0.228 & nd & -0.075 & -0.133 & -0.024 \\
\hline $\mathrm{Cd}$ & & 1.000 & $0.718^{*}$ & $0.728^{\star}$ & nd & -0.338 & -0.563 & 0.572 \\
\hline $\mathrm{Cr}$ & & & 1.000 & 0.581 & nd & 0.116 & -0.385 & 0.451 \\
\hline $\mathrm{Ni}$ & & & & 1.000 & nd & -0.157 & -0.339 & 0.462 \\
\hline As & & & & & nd & nd & nd & nd \\
\hline $\mathrm{Zn}$ & & & & & & 1.000 & 0.237 & -0.399 \\
\hline $\mathrm{Cu}$ & & & & & & & 1.000 & 0.032 \\
\hline $\mathrm{Fe}$ & & & & & & & & 1.000 \\
\hline \multicolumn{9}{|l|}{ Leaf } \\
\hline $\mathrm{Pb}$ & 1.000 & -0.576 & 0.236 & 0.614 & nd & 0.303 & 0.161 & 0.214 \\
\hline $\mathrm{Cd}$ & & 1.000 & -0.552 & -0.189 & nd & 0.145 & -0.266 & -0.417 \\
\hline $\mathrm{Cr}$ & & & 1.000 & 0.282 & nd & -0.617 & 0.085 & -0.137 \\
\hline $\mathrm{Ni}$ & & & & 1.000 & nd & -0.008 & -0.047 & 0.026 \\
\hline As & & & & & nd & nd & nd & nd \\
\hline $\mathrm{Zn}$ & & & & & nd & 1.000 & -0.349 & 0.211 \\
\hline $\mathrm{Cu}$ & & & & & nd & & 1.000 & 0.198 \\
\hline $\mathrm{Fe}$ & & & & & nd & & & 1.000 \\
\hline Fruits & & & & & nd & & & \\
\hline $\mathrm{Pb}$ & 1.000 & 0.005 & 0.021 & -0.305 & nd & -0.051 & -0.393 & 0.017 \\
\hline $\mathrm{Cd}$ & & 1.000 & -0.215 & $0.691^{*}$ & nd & -0.376 & $0.759^{*}$ & 0.052 \\
\hline $\mathrm{Cr}$ & & & 1.000 & 0.102 & nd & 0.596 & -0.552 & -0.195 \\
\hline $\mathrm{Ni}$ & & & & 1.000 & nd & -0.494 & 0.526 & -0.212 \\
\hline As & & & & & nd & nd & nd & nd \\
\hline $\mathrm{Zn}$ & & & & & & 1.000 & -0.457 & 0.245 \\
\hline $\mathrm{Cu}$ & & & & & & & 1.000 & 0.258 \\
\hline $\mathrm{Fe}$ & & & & & & & & 1.000 \\
\hline
\end{tabular}

Note: nd - not detected.

distribution of heavy metals in various tissues of apple tree. There are different variations in the ability of to take up heavy metals through their root tissues and transport them to the edible parts of the plants. This variation depends on the physicochemical properties of heavy metals, industrial region, species of crops, cultivation strategy, soil type and growing conditions. Previous studies showed that the higher the concentration of heavy metals on soil, the higher the probability will be in plant cultures (Mapanda et al., 2007). Poniedzialek (Poniedzialek et al., 1999) found the differences between cultures at the level of accumulation of heavy metals in specific organs. Like lead, cadmium is also known for its toxic and negative effects on human health. Cadmium can accumulate in the human body and can cause kidney dysfunction, skeletal damage and reproductive deficiency. The cadmium content in the literature was reported in the range of and 0.0002 $0.527 \mathrm{mg} / \mathrm{kg}$ in fruit foods from the Greek market (Karavoltsos et al., 2002).

In our study, fruit analysis from all sampling points was contaminated by an excessive amount of $\mathrm{Cd}$ compared to the permitted limit $(0.05 \mathrm{mg} / \mathrm{kg})$ proposed by FAO / WHO (1995). 
Table 5. Calculation of correlation coefficient (r) between heavy metals in soil, shoot, leaf and fruit to apple cultivar (delicious v. supercheef) with $\mathrm{m} 26$ rootstock

\begin{tabular}{|c|c|c|c|c|c|c|c|c|}
\hline & $\mathrm{Pb}$ & $\mathrm{Cd}$ & $\mathrm{Cr}$ & $\mathrm{Ni}$ & As & $\mathrm{Zn}$ & $\mathrm{Cu}$ & $\mathrm{Fe}$ \\
\hline \multicolumn{9}{|c|}{ Shoot } \\
\hline $\mathrm{Pb}$ & 1.000 & -0.354 & $-0.742^{*}$ & -0.263 & nd & -0.456 & 0.017 & 0.023 \\
\hline $\mathrm{Cd}$ & & 1.000 & -0.009 & 0.535 & nd & -0.471 & 0.209 & -0.535 \\
\hline $\mathrm{Cr}$ & & & 1.000 & 0.132 & nd & 0.508 & -0.074 & 0.271 \\
\hline $\mathrm{Ni}$ & & & & 1.000 & nd & -0.277 & 0.584 & 0.153 \\
\hline As & & & & & nd & nd & nd & nd \\
\hline $\mathrm{Zn}$ & & & & & & 1.000 & -0.354 & 0.388 \\
\hline $\mathrm{Cu}$ & & & & & & & 1.000 & 0.291 \\
\hline $\mathrm{Fe}$ & & & & & & & & 1.000 \\
\hline \multicolumn{9}{|l|}{ Leaf } \\
\hline $\mathrm{Pb}$ & 1.000 & -0.361 & 0.227 & 0.453 & nd & -0.291 & -0.062 & 0.288 \\
\hline $\mathrm{Cd}$ & & 1.000 & -0.341 & -0.408 & nd & 0.566 & -0.301 & -0.277 \\
\hline $\mathrm{Cr}$ & & & 1.000 & 0.162 & nd & 0.453 & -0.387 & 0.203 \\
\hline $\mathrm{Ni}$ & & & & 1.000 & nd & -0.255 & -0.142 & 0.601 \\
\hline As & & & & & nd & nd & nd & nd \\
\hline $\mathrm{Zn}$ & & & & & & 1.000 & $-0.808^{* *}$ & 0.025 \\
\hline $\mathrm{Cu}$ & & & & & & & 1.000 & -0.334 \\
\hline $\mathrm{Fe}$ & & & & & & & & 1.000 \\
\hline \multicolumn{9}{|c|}{ Fruits } \\
\hline $\mathrm{Pb}$ & 1.000 & 0.155 & 0.256 & -0.197 & nd & -0.371 & -0.614 & 0.218 \\
\hline $\mathrm{Cd}$ & & 1.000 & -0.251 & -0.171 & nd & 0.591 & 0.009 & 0.041 \\
\hline $\mathrm{Cr}$ & & & 1.000 & 0.407 & nd & -0.433 & -0.446 & -0.083 \\
\hline $\mathrm{Ni}$ & & & & 1.000 & nd & 0.071 & -0.354 & -0.334 \\
\hline As & & & & & nd & nd & nd & nd \\
\hline $\mathrm{Zn}$ & & & & & & 1.000 & 0.264 & 0.169 \\
\hline $\mathrm{Cu}$ & & & & & & & 1.000 & 0.234 \\
\hline $\mathrm{Fe}$ & & & & & & & & 1.000 \\
\hline
\end{tabular}

Note: $n d-$ not detected.

The results obtained in this study were also consistent with those found in apples $(2.21 \mathrm{mg} / \mathrm{kg})$ (Hamurcu et al. 2010).

The above-mentioned results show that $\mathrm{Cd}$ has a high capacity to be transferred from soil to edible parts of fruit in agricultural lands of the Drenas region. This can be attributed to the competition between $\mathrm{Cd}^{2+}$ and $\mathrm{Ca}^{2+}$. It is easier for $\mathrm{Ca}^{2+}$ to be replaced by $\mathrm{Cd}^{2+}$ than other metals due to their same valence (Kim et al. 2002). In addition, $\mathrm{Ca}$ is an essential element for plants and can enter plant tissues through active transport, while most heavy metals (as non-essential elements) can only be introduced into plant tissues through passive methods (e.g., concentration diffusion and permeation) Costa and Morel 1993).

The concentration of $\mathrm{Cr}$ in delicious apple cultivars in three rootstocks, i.e. mm106, $\mathrm{m} 26$ and $\mathrm{m} 9$, in the contaminated studied fields was greater than in the reference area. The content of chromium in the literature was reported in the range of $1.48-6.43 \mathrm{mg} / \mathrm{kg}$ in wet weight in various summer fruits from Pakistan (Zahoor et al., 2003). There is no information on the maximum chromium levels in dried fruit samples (Anonymous 2002). Chromium (III) is an essential nutrient that empowers the action of insulin and thus affects the metabolism of carbohydrates, lipids and proteins. However, chromium (VI) is carcinogenic (Tuzen and Soylak 2006). This high concentration of $\mathrm{Cr}$ can be dangerous to the local community and fauna of the study area (Yang et al., 2011).

The Ni levels in fruit were many times higher than the maximum allowed limit $(0.3 \mathrm{mg} / \mathrm{kg})(\mathrm{Li}$ et al., 2012). The content of nickel in literature was reported in the range of $1.0-8.9 \mathrm{mg} / \mathrm{kg}$ in some fruits from Pakistan (Zahoor et al., 2003). In the study area, the nickel concentration in plant tissues was observed a few times higher than the reference site. Ni is an important and essential element to plants; however, its excess causes variable symptoms of toxicity (Zornoza et al., 1999). The low content of copper in apple fruits is most 
Table 6. Calculation of correlation coefficient (r) between heavy metals in soil, shoot, leaf and fruit to apple cultivar (delicious $\mathrm{v}$. supercheef) with $\mathrm{m} 9$ rootstock

\begin{tabular}{|c|c|c|c|c|c|c|c|c|}
\hline & $\mathrm{Pb}$ & $\mathrm{Cd}$ & $\mathrm{Cr}$ & $\mathrm{Ni}$ & As & $\mathrm{Zn}$ & $\mathrm{Cu}$ & $\mathrm{Fe}$ \\
\hline \multicolumn{9}{|c|}{ Shoot } \\
\hline $\mathrm{Pb}$ & 1.000 & 0.207 & -0.062 & 0.379 & nd & -0.298 & 0.041 & -0.222 \\
\hline $\mathrm{Cd}$ & & 1.000 & -0.312 & -0.076 & nd & -0.209 & -0.067 & $-0.791^{\text {t* }}$ \\
\hline $\mathrm{Cr}$ & & & 1.000 & -0.076 & nd & 0.471 & 0.063 & 0.088 \\
\hline $\mathrm{Ni}$ & & & & 1.000 & nd & -0.553 & 0.159 & 0.497 \\
\hline As & & & & & nd & nd & nd & nd \\
\hline $\mathrm{Zn}$ & & & & & & 1.000 & -0.151 & -0.174 \\
\hline $\mathrm{Cu}$ & & & & & & & 1.000 & 0.271 \\
\hline $\mathrm{Fe}$ & & & & & & & & 1.000 \\
\hline \multicolumn{9}{|l|}{ Leaf } \\
\hline $\mathrm{Pb}$ & 1.000 & $0.706^{*}$ & 0.101 & 0.198 & nd & -0.498 & 0.241 & -0.033 \\
\hline $\mathrm{Cd}$ & & 1.000 & 0.006 & 0.528 & nd & $-0.764^{* *}$ & 0.448 & 0.232 \\
\hline $\mathrm{Cr}$ & & & 1.000 & -0.344 & nd & -0.454 & 0.197 & -0.302 \\
\hline $\mathrm{Ni}$ & & & & 1.000 & nd & -0.458 & 0.061 & 0.058 \\
\hline As & & & & & nd & nd & nd & nd \\
\hline $\mathrm{Zn}$ & & & & & & 1.000 & -0.449 & 0.262 \\
\hline $\mathrm{Cu}$ & & & & & & & 1.000 & 0.051 \\
\hline $\mathrm{Fe}$ & & & & & & & & 1.000 \\
\hline \multicolumn{9}{|c|}{ Fruits } \\
\hline $\mathrm{Pb}$ & 1.000 & -0308 & 0.086 & -0.092 & nd & -0.247 & 0.057 & 0.044 \\
\hline $\mathrm{Cd}$ & & 1.000 & $0.632^{*}$ & 0.208 & nd & $0.681^{*}$ & 0.194 & -0.439 \\
\hline $\mathrm{Cr}$ & & & 1.000 & 0.047 & nd & 0.316 & 0.201 & -0.413 \\
\hline $\mathrm{Ni}$ & & & & 1.000 & nd & 0.029 & -0.052 & 0.289 \\
\hline As & & & & & nd & nd & nd & nd \\
\hline $\mathrm{Zn}$ & & & & & & 1.000 & 0.073 & 0.023 \\
\hline $\mathrm{Cu}$ & & & & & & & 1.000 & -0.031 \\
\hline $\mathrm{Fe}$ & & & & & & & & 1.000 \\
\hline
\end{tabular}

Note: $n d$ - not detected.

likely due to the poor movement of copper in plants as well as the high concentration of zinc in soil known to have an antagonistic effect on the copper absorption (Chaudhry et al 1973).

\section{CONCLUSIONS}

The results obtained from this work showed that the concentrations of heavy metals $(\mathrm{Pb}, \mathrm{Cd}$, $\mathrm{Cr}, \mathrm{Ni}, \mathrm{As}, \mathrm{Zn}, \mathrm{Cu}$ and $\mathrm{Fe}$ ) in the soil samples, shoots, leaves and fruits in the Drenas region were higher than the concentrations of these metals in the control samples. When the results of this study were compared with comparable studies, the heavy metal levels were found to be higher, especially in fruits. The study showed that some consumed fruits were highly contaminated with some heavy metals and exceeded their standards established by FAO/WHO. The differences in the bioaccumulation of heavy metals in the apple tissues (delicious) may be explained by the type of rootstock used. The high accumulation ratio values for $\mathrm{Pb}(1.1), \mathrm{Cd}$ (0.62), $\mathrm{Cr}(0.93)$ and $\mathrm{Ni}$ $(0.46)$ were characteristic for the investigated species and indicate the accumulation ability.

\section{Acknowledgements}

The authors are grateful to Mr. Leke Duhani, for the great help given to carry out this research.

\section{REFERENCES}

1. Akgüç N, Özyiğit II, Yarc1 C. 2008. Pyracantha coccinea Roem. (Rosaceae) as a biomonitor for $\mathrm{Cd}, \mathrm{Pb}$ and $\mathrm{Zn}$ in Mugla Province (Turkey). Pakistan Journal of Botany 40 (4): 1767-1776.

2. Huseyinova R, Kutbay HG, Bilgin A, Kilic D, Horuz A, Kirmanoglu C. 2009. Sulphur and Some Heavy Metal Contents in Foliage of Corylus avellana and Some Roadside Native Plants in Ordu Province, Turkey. Ekoloji 18 (70): 10-16. 
3. Vontsa D., Grimanis A., Samara C. 1986. Trace elements in vegetables grown in industrial areas in relation to soil and air particulate matter, Environmental Sollution, 94, 325-335.

4. McLaughlin, M. J., Smolders, E., Degryse, F., \& Rietra, R. 2011. Uptake of metals from soil into vegetables. In: F.A. Swartjes (Ed.), Dealing with contaminated sites: from theory towards practical application. Heidelberg: Springer. doi:10.1007/ 978-90-481-9757-6_8.

5. Khan, S., Rehman, S., Zeb Khan, A., Amjad Khan, M., \& Tahir Shah, M. 2010. Soil and vegetables enrichment with heavy metals from geological sources in Gilgit, northern Pakistan. Ecotoxicology and Environmental Safety, 73(7), 1820-1827.

6. Brioschi, L., Steinmann, M., Lucot, E., Pierret, M. C., Stille, P., Prunier, J., \& Badot, P. M. 2013. Transfer of rare earth elements (REE) from natural soil to plant systems: implications for the environmental availability of anthropogenic REE. Plant and Soil, 366, 143-163. doi:10.1007/s11104-012-1407-0.

7. García, M.Á., Alonso, J., \& Melgar, M.J. 2009. Lead in edible mushrooms: levels and bioaccumulation factors. Journal of Hazardous Materials, 167(1-3), 777-783.

8. Gupta S, Nayek S, Saha RH, Satpati S. 2008. Assessment of heavy metal accumulation in macrophyte, agricultural soil and crop plants adjacent to discharge zone of sponge iron factory. Environ Geol 55: 731-739.

9. Karavoltsos S, Sakellari A, Dimopoulos M, Dasenakis M, Scoullos M. 2002. Cadmium content in foodstuffs from the Greek market. Food Additives Contam 19: 954-962.

10. Costa, G., \& Morel, J.L. 1993. Cadmium uptake by Lupinus albus (L): cadmium excretion, a possible mechanism of cadmium tolerance. Journal of Plant Nutrition, 16(10), 1921-1929.

11. Kim, Y.Y., Yang, Y.Y. \& Lee, Y., 2002. Pb and Cd uptake in rice roots. Physiologia Plantarum, (116): 368-372.

12. Zahoor A, Jafar M, Saqib M. 2003. Elemental distribution in summer fruits of Pakistan. Nutr Food Sci 33: 203-207.

13. Anonymous. 2002. Regulation of setting maximum levels for certain contaminants in foodstuffs. Official Gazette, Issue 24908, 16 October.

14. Tuzen M, Soylak M. 2006. Chromium speciation in environmental samples by solid phase extraction on Chromosorb 108. J Hazard Mater 129: 266-273.

15. Yang Z, LuW, Long Y, Bao X, Yang Q. 2011. Assessment of heavy metals contamination in urban topsoil from Changchun City, China. J Geochem Exp 108: 27-38.

16. Zornoza P, Robles S, Martin N. 1999. Alleviation of nickel toxicity by ammonium supply to sunflower plants. Plant Soil 208: 221- 226.
17. Poniedzialek, M., Ciura, J., Stokowska, E. and Sekara, A. 1999. Control of the contamination of lettuce crop with heavy metals by the selection of a site and a cultivar. Scientific Works of the Lithuanian Institute of Horticulture and Lithuanian University of Agriculture. Hort. Veg. Grow. 18: 146-150.

18. Lokeshwari H, Chandrappa G.T. 2006. Impact of heavy metal contamination of Bellandur Lake on soil and cultivated vegetation. Current Science, 91, 622-627.

19. Zhen H. 2008. Pollution characteristics of heavy metal in grains and fruits at both sides of ShenyangDalian expressway. Journal of Meteorology and Environment, 24, 1-5.

20. Xiao Z.L, Cong Q, Qu J. 2010. Assessment of heavy metal pollution in orchard soil and its affections to fruit quality around molybdenum mining area. Science Technology and Engineering, 10, 5831-5834.

21. Chaudhry, F.M., Sharif, M., Latif, A., Qureshi, R.H. 1973. Zinc-copper antagonism in the nutrition of rice (Oryza sativa L.). Plant and Soil, 38(3): 573-580.

22. FAO/WHO 1995. Codex General Standard for Contaminants and Toxins in Food and Feed (193-1995), pp. 31-32.

23. Liu J, Wang J, Qi J, Li X, Chen Y, Wang C, Wu Y. 2012. Heavy Metal Contamination in Arable Soils and Vegetables around a Sulfuric Acid Factory, China. Clean Soil Air Water 40: 766-772.

24. Zahoor, T. 2003. High molecular weight glutenin subunit composition and multivariate analysis for quality traits of common wheats grown in Pakistan. Ph.D. Thesis, Inst. Food Sci. \& Tech., University of Agriculture, Faisalabad, Pakistan.

25. De Santis D, Moresi M. 2007. Production of alizarin extracts from Rubia tinctorum and assessment of their dyeing properties. Ind Crops Products, 26: 151-162.

26. D’Mello JPF. 2003. Food safety: Contaminants and toxins. Wallingford, Oxon and Cambridge, MA: CABI Publishing. pp. 480.

27. Adamo, P., Iavazzo, P., Albanese, S., Agrelli, D., De Vivo, B., \& Lima, A. 2014. Bioavailability and soil-to-plant transfer factors as indicators of potentially toxic element contamination in agricultural soils. Science of the Total Environment, 500-501, 11-22.

28. Rizaj, M., Beqiri, E., McBow, Z., Kongoli, F. 2008. The mineral base and productive capacities of metals and non-metals of Kosovo. JOM, 60(8), 18-22.

29. Mapanda F, Mangwayana E.N, Nyamangara J, Giller K E. 2007. Uptake of heavy metals by vegetables irrigated using wastewater and the subsequent risks in Harare, Zimbabwe. Physics and Chemistry of the Earth (Parts A/B/C), 32, 1399-1405.

30. Kabata-Pendias, A. and Pendias, H. 1989. Trace Elements in the Soil and Plants. CRC Press, Florida. 